\title{
ASUPAN VITAMIN A DAN SENG (Zn) DENGAN KEJADIAN DERMATITIS PADA BALITA USIA 2-5 TAHUN DI KELURAHAN JOMBLANG KECAMATAN CANDISARI KOTA SEMARANG
}

\section{Intake of Vitamin A and Zinc (Zn) with The Incidence of Dermatitis in Children Aged 2-5 Years Old in Jomblang Village Candisari District Semarang City}

\author{
Desy Amelia Ardi ${ }^{1}$, Aryu Candra ${ }^{1}$, Fillah Fithra Dieny ${ }^{1 *}$ \\ 'Departemen IImu Gizi, Fakultas Kedokteran, Universitas Diponegoro \\ JI. Prof. H. Soedarto, SH. Tembalang, Semarang, Jawa Tengah, Indonesia \\ *e-mail: fillahdieny@gmail.com
}

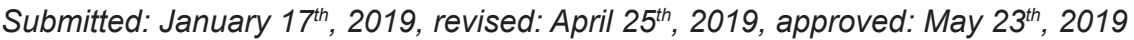

\begin{abstract}
Background. The incidence of dermatitis in children has been increasing in recent years. Vitamin $A$ and zinc deficiency affect dermatitis related to its function in the immune system. Objective. Analyze the significant risk of vitamin A and zinc intake history towards the incidence of dermatitis in children aged 2-5 years old. Method. This research was a retrospective observational with case-control study approach. The subjects were children aged 2-5 years old with 29 case and 29 control choose using consecutive sampling technique. Data collected was vitamin $A$ and zinc intake history using Semi-Quantitative Food Frequency Questionnaire (SQ-FFQ), also collected data of personal hygiene and environmental sanitation using standardized questionnaires. Data analyzed using Chi-Square and multiple logistic regression test. Result. The result of this research showed total of 79.3 percent of subjects were 2-3 years old. The nutritional status was averagely normal based on BW/A, BH/A, and BW/BH. The author found subjects with a deficient vitamin A intake history (29.3\%), insufficient zinc intake history (39.7\%), having poor personal hygiene (46.6\%), and poor environmental sanitation (79.3\%). The results showed vitamin $A$ intake history $(p=0.0001)$, and zinc intake history $(p=0.001)$, personal hygiene $(p=0.008)$, environmental sanitation $(p=0.021)$ were associated with dermatitis incidence. Vitamin A intake history $(p=0.019)$ and zinc intake history $(p=0.043)$ were the most at risk factors for the incidence of dermatitis. Conclusion. Subjects with a deficient vitamin A intake history had 7.9 times risk for having dermatitis. Meanwhile, subjects with a deficient zinc intake history had 4.3 times chance for having the diseases.
\end{abstract}

Keywords: dermatitis, environmental sanitation, personal hygiene, vitamin A intake history, zinc intake history

\section{ABSTRAK}

Latar Belakang. Kejadian dermatitis pada anak terus meningkat beberapa tahun terakhir. Defisiensi vitamin A dan seng memengaruhi kejadian dermatitis terkait fungsi dalam sistem imun. Tujuan. Penelitian ini bertujuan untuk menganalisis besar risiko riwayat asupan vitamin $\mathrm{A}$ dan asupan seng terhadap kejadian dermatitis pada anak di bawah lima tahun (balita) berusia 2-5 tahun. Metode. Penelitian ini merupakan penelitian observasional retrospektif dengan pendekatan case control. Subjek yang diambil adalah balita berusia 2-5 tahun sebanyak 58 subjek terdiri dari 29 subjek kasus dan 29 subjek kontrol diambil dengan teknik consecutive sampling. Data yang dikumpulkan yaitu riwayat asupan vitamin $A$ dan asupan seng yang diambil menggunakan Semi Quantitative Food Frequency Questionnaire (SQ-FFQ), data mengenai personal hygiene dan sanitasi lingkungan diambil dengan pengisian kuesioner. Analisis data dilakukan dengan uji Chi-Square dan uji regresi logistik ganda. Hasil. Hasil penelitian menunjukkan sebanyak 79,3 persen subjek merupakan anak-anak berusia 2-3 tahun. Status gizi rata-rata subjek adalah 
normal berdasarkan BB/U, TB/U maupun BB/TB. Terdapat subjek dengan riwayat asupan vitamin A kurang $(29,3 \%)$, riwayat asupan seng kurang $(39,7 \%)$, personal hygiene tidak baik $(46,6 \%)$, sanitasi lingkungan tidak baik $(79,3 \%)$. Riwayat asupan vitamin $A(p=0,0001)$, riwayat asupan seng $(p=0,001)$, personal hygiene $(p=0,008)$, sanitasi lingkungan $(p=0,021)$ berhubungan dengan dermatitis. Riwayat asupan vitamin $\mathrm{A}(p=0,019)$ dan riwayat asupan seng $(p=0,043)$ paling berisiko terhadap kejadian dermatitis. Kesimpulan. Subjek dengan riwayat asupan vitamin A kurang dari kebutuhan berisiko 7,9 kali lebih besar mengalami dermatitis, sedangkan subjek dengan riwayat asupan seng kurang dari kebutuhan berisiko 4,3 kali lebih besar mengalami dermatitis.

Kata kunci: dermatitis, sanitasi lingkungan, personal hygiene, riwayat asupan vitamin A, riwayat asupan seng

\section{PENDAHULUAN}

Dermatitis merupakan salah satu masalah kesehatan masyarakat yang kejadiannya terus meningkat dalam beberapa tahun terakhir. Dermatitis adalah peradangan kulit (epidermis dan dermis) sebagai respon terhadap pengaruh faktor eksogen dan atau faktor endogen. Dermatitis sering dijumpai pada anak karena daya tahan kulit terhadap invasi patogen belum sesempurna orang dewasa dan menjadi masalah utama penyebab tingginya angka morbiditas pada anak terutama di negara berkembang dan wilayah beriklim tropis karena sifatnya yang residif atau kambuh jika terpapar faktor risiko yang dapat memicu dermatitis muncul dan menjadi kronis sehingga memengaruhi kualitas hidup penderita. ${ }^{2}$

Usia balita merupakan masa dimana terjadi pertumbuhan dan perkembangan yang cepat sehingga perlu asupan makan yang cukup sesuai dengan kebutuhan untuk mencapai pertumbuhan dan perkembangan yang optimal. ${ }^{3}$ Penelitian dalam dekade terakhir mengonfirmasi bahwa defisiensi gizi dapat mengubah respon imun dan menyebabkan insiden penyakit infeksi seperti infeksi pada kulit menjadi lebih tinggi, menyebabkan peningkatan mortalitas terutama pada anak-anak karena kulit merupakan organ pertama yang terkena dampak saat mengalami defisiensi zat gizi. ${ }^{4,5}$ Penyakit dermatitis berdampak besar pada kesejahteraan penderita khususnya anak, baik secara fisik maupun psikologis. Anak akan mengalami kesulitan melakukan kegiatan seperti bermain, bersekolah, mengganggu tidur dan kegiatan lainnya, sering diejek dan mengalami kesulitan bergaul dengan teman-teman dan masyarakat sosial. ${ }^{3}$

Prevalensi penyakit kulit di negara berkembang menunjukkan angka yang tinggi yaitu 21-87 persen. ${ }^{2}$ Tingginya angka ini belum dianggap serius sebagai masalah kesehatan yang signifikan dalam pengembangan strategi kesehatan masyarakat. ${ }^{6}$ Beberapa penelitian melaporkan bahwa gangguan penyakit kulit pada anak kebanyakan terjadi di negara berpenghasilan rendah, seperti Indonesia., Dermatitis yang sering muncul terutama pada anak adalah dermatitis atopik 0,69 persen, dermatitis seboroik 2,32 persen yang menyerang 2-5 persen penduduk. Menurut Kelompok Studi Dermatologi Anak Indonesia (KSDAI) dari lima kota besar di Indonesia pada tahun 2000, dermatitis atopik menempati peringkat pertama $(23,67 \%)$ dari sepuluh besar penyakit kulit anak dan dari sepuluh rumah sakit besar yang tersebar di seluruh Indonesia dan pada tahun 2010 kejadian dermatitis mencapai 36 persen angka kejadian. ${ }^{8}$ Data Kementerian Kesehatan Indonesia pada tahun 2011, gambaran kasus penyakit kulit dan subkutan lainnya merupakan peringkat ketiga dari sepuluh penyakit utama dengan 86 persen adalah dermatitis. Sebanyak empat belas provinsi mempunyai prevalensi dermatitis diatas prevalensi nasional termasuk 
didalamnya Provinsi Jawa Tengah. ${ }^{3}$ Namun, hingga saat ini angka kejadian dermatitis di Kota Semarang belum diketahui secara pasti.

Defisiensi mikronutrien membawa dampak luas dan fatal, sehingga belakangan ini peneliti banyak memberikan fokus pada zat gizi mikronutrien. ${ }^{9}$ Salah satu penyebab timbulnya dermatitis adalah karena defisiensi beberapa jenis mikronutrien seperti vitamin A dan seng $(\mathrm{Zn})$. Defisiensi vitamin paling banyak adalah defisiensi vitamin A yang memengaruhi hingga 254 juta anak di seluruh dunia. ${ }^{10}$ Kecukupan asupan vitamin A membawa efek dalam sistem imun seseorang yaitu dapat meningkatkan imunitas seluler dan humoral, karena selain dibutuhkan untuk mempertahankan keutuhan fungsi dan struktur epitel, vitamin A dibutuhkan dalam respon mitogenik dari limfosit $T$ dan limfosit B serta menjaga keseimbangan $\mathrm{TH} 1$ dan $\mathrm{TH} 2 .{ }^{11,12}$ Vitamin A juga berperan dalam proses diferensiasi sel epidermis. ${ }^{13}$

Seng dapat ditemukan pada semua jaringan tubuh. Kulit dan adneksanya merupakan organ dengan kandungan seng terbanyak kedua sesudah tulang dan otot, sehingga pada defisiensi seng dapat ditemukan berbagai kelainan kulit diantaranya adalah dermatitis, kulit kering dan kasar. ${ }^{14}$ Seng dibutuhkan tubuh karena merupakan mineral yang membantu keseimbangan metabolisme yang berkaitan dengan respon imun. ${ }^{15}$ Suplementasi seng dapat memperbaiki gangguan respon imun seluler pada orang dengan defisiensi seng. ${ }^{11}$ Di negara berkembang yang sering terjadi malnutrisi, defisiensi seng masih menjadi masalah kesehatan karena defisiensi seng meningkatkan risiko morbiditas dan mortalitas pada anak. ${ }^{16}$

Jumlah penduduk di Kelurahan Jomblang, Kecamatan Candisari, Kota Semarang cukup padat dan sebagian besar memiliki status sosial ekonomi menengah ke bawah. Berdasarkan catatan kader posyandu, hampir setiap tahun terdapat kasus balita gizi kurang dan gizi buruk, dimana defisiensi mikronutrien sering terjadi pada anak berstatus gizi kurang. Penelitian sebelumnya menunjukkan balita yang mengalami defisiensi mikronutrien termasuk defisiensi seng mencapai 26,2 persen. ${ }^{17-19}$

Berdasarkan uraian latar belakang di atas, maka penulis tertarik meneliti apakah asupan vitamin $\mathrm{A}$ dan seng ( $\mathrm{Zn}$ ) merupakan faktor risiko kejadian dermatitis pada balita usia 2-5 tahun di Kelurahan Jomblang.

\section{METODE}

Penelitian ini merupakan penelitian observasional retrospektif dengan pendekatan case control untuk menganalisis besar risiko asupan vitamin $A$ dan seng terhadap kejadian dermatitis pada balita. Penelitian dilakukan di Kelurahan Jomblang, Kecamatan Candisari, Kota Semarang dengan melakukan anamnesis dan pemeriksaan fisik di beberapa posyandu serta pengukuran antropometri dan pengisian kuesioner secara door to door ke rumah responden.

Populasi target penelitian adalah balita yang mengalami dermatitis (kasus) dan balita yang tidak mengalami dermatitis (kontrol) di Kota Semarang. Populasi terjangkau penelitian adalah balita usia 2-5 tahun yang mengalami dermatitis dan balita usia 2-5 tahun yang tidak mengalami dermatitis di Kelurahan Jomblang, Kecamatan Candisari, Kota Semarang. Perbandingan sampel 1 kasus : 1 kontrol. Besar sampel minimal dihitung dengan menggunakan rumus studi case control. Berdasarkan rumus perhitungan sampel, maka besar sampel minimal dalam penelitian ini adalah masing-masing 26 sampel untuk kelompok kasus dan kontrol. Untuk mengantisipasi drop out, ditambahkan 
10 persen pada tiap-tiap kelompok, sehingga jumlah sampel yang digunakan masing-masing 29 sampel untuk kelompok kasus dan kelompok kontrol. Pemilihan sampel dengan metode consecutive sampling. Pemilihan kelompok kontrol dengan melakukan matching terkait usia, jenis kelamin, dan indeks antropometri berat badan menurut tinggi badan (BB/TB).

Pengambilan sampel diawali dengan pengisian informed consent oleh responden apabila setuju mengikuti penelitian ini. Setelah mendapat persetujuan responden, peneliti melakukan skrining subjek berupa anamnesis dan pemeriksaan fisik dengan bantuan dokter untuk menentukan kelompok kasus dan kelompok kontrol. Selanjutnya, dilakukan pengisian kuesioner data identitas subjek yang didalamnya ada pernyataan dermatitis dari dokter sebagai variabel terikat, kuesioner kebiasaan makan pasien dengan Semi-Quantitative Food Frequency Questionnaire (SQ-FFQ) untuk mengetahui riwayat asupan subjek sebagai variabel bebas, kuesioner tertutup mengenai personal hygiene dan sanitasi lingkungan subjek untuk mengetahui kebersihan diri dan lingkungan sebagai variabel perancu. Kuesioner SQ-FFQ yang dibuat sudah disesuaikan kelompok subjek penelitian (balita) dengan memperhatikan kebiasaan makannya dan sudah memasukkan bahan makanan sumber vitamin A dan seng yang biasa dikonsumsi, termasuk makanan yang sudah difortifikasi vitamin A seperti susu formula, minyak goreng, suplemen penambah nafsu makan, dan lain-lain. Kuesioner SQFFQ sebelumnya telah diujicobakan dan sudah dilakukan validasi terlebih dahulu. Pengisian kuesioner dilakukan dengan metode wawancara mendalam kepada orangtua atau pengasuh subjek penelitian. Hasil dari SQ-FFQ menunjukkan keseringan penggunaan bahan makanan serta jumlah berat bahan makanan per kali penggunaan sehingga bisa menunjukkan rata-rata asupan per hari. ${ }^{20}$

Kuesioner personal hygiene digunakan untuk melihat hubungan kebersihan perorangan dengan keluhan penyakit kulit. Hasil pengisian kuesioner kemudian diberikan kode sesuai dengan perolehan nilai. Apabila kuesioner personal hygiene memiliki nilai 0-33 atau jawaban benar $\leq 75$ persen maka dikategorikan personal hygiene tidak baik atau dan nilai 34-45 atau jawaban benar $>75$ persen maka dikategorikan personal hygiene baik. ${ }^{21}$ Kuesioner sanitasi lingkungan digunakan untuk menilai status kesehatan suatu lingkungan. Kecukupan asupan subjek berdasarkan Angka Kecukupan Gizi (AKG) tahun 2013. Hasil pengisian kuesioner kemudian dinilai sesuai dengan Keputusan Menteri Kesehatan RI Nomor 829/Menkes/SKI VII/1999 dan akan dilakukan coding. Penelitian ini telah mendapatkan perijinan Ethical Clearance dari Komisi Etik Penelitian dan Kesehatan FK UNDIP dan RSUP dr. Kariadi Semarang dengan Nomor 202/EC/FK-RSDK/IV/2018.

Data yang sudah dikumpulkan kemudian diolah menggunakan program Statistical Packages for Social Science (SPSS) dalam melakukan analisis univariat untuk mendeskripsikan variabel. Analisis bivariat untuk mengetahui hubungan masing-masing variabel dengan variabel terikat menggunakan uji ChiSquare (Uji X2) dan analisis multivariat untuk menganalisis variabel yang paling berpengaruh terhadap kejadian dermatitis menggunakan uji regresi logistik ganda.

\section{HASIL}

\section{Karakteristik Subjek}

Berdasarkan data yang diperoleh, diketahui karakteristik subjek penelitian adalah sebagai berikut: 
Tabel 1. Karakteristik Subjek

\begin{tabular}{|c|c|c|}
\hline Variabel & $\mathrm{n}$ & $\%$ \\
\hline \multicolumn{3}{|l|}{ Usia } \\
\hline 2-3 tahun & 46 & 79,3 \\
\hline 4-5 tahun & 12 & 20,7 \\
\hline \multicolumn{3}{|l|}{ Jenis kelamin } \\
\hline Laki-laki & 24 & 41,4 \\
\hline Perempuan & 34 & 58,6 \\
\hline \multicolumn{3}{|l|}{ BB/U } \\
\hline Gizi kurang & 10 & 17,2 \\
\hline Gizi baik & 47 & 81,1 \\
\hline Gizi lebih & 1 & 1,7 \\
\hline \multicolumn{3}{|l|}{ TB/U } \\
\hline Sangat pendek & 2 & 3,4 \\
\hline Pendek & 12 & 20,7 \\
\hline Normal & 42 & 72,5 \\
\hline Tinggi & 2 & 3,4 \\
\hline \multicolumn{3}{|l|}{ BB/TB } \\
\hline Kurus & 2 & 3,4 \\
\hline Normal & 50 & 86,2 \\
\hline Gemuk & 6 & 10,4 \\
\hline \multicolumn{3}{|c|}{ Riwayat asupan vitamin A } \\
\hline Kurang & 17 & 29,3 \\
\hline Cukup & 41 & 70,7 \\
\hline \multicolumn{3}{|l|}{ Riwayat asupan seng } \\
\hline Kurang & 23 & 39,7 \\
\hline Cukup & 35 & 60,3 \\
\hline \multicolumn{3}{|l|}{ Personal hygiene } \\
\hline Tidak baik & 27 & 46,6 \\
\hline Baik & 31 & 53,4 \\
\hline \multicolumn{3}{|l|}{ Sanitasi lingkungan } \\
\hline Tidak baik & 46 & 79,3 \\
\hline Baik & 12 & 20,7 \\
\hline
\end{tabular}

Berdasarkan tabel karakteristik subjek (Tabel 1) diketahui sebanyak 79,3 persen subjek penelitian berusia 2-3 tahun. Perbandingan jenis kelamin subjek penelitian hampir sama antara laki-laki dan perempuan. Status gizi subjek penelitian rata-rata normal berdasarkan BB/U, TB/U maupun BB/TB. Sebanyak 17 subjek $(29,3 \%)$ masih memiliki riwayat asupan vitamin
A kurang, 23 subjek (39,7\%) masih memiliki riwayat asupan seng kurang dan 27 subjek $(46,6 \%)$ masih memiliki personal hygiene yang tidak baik. Sedangkan jika melihat sanitasi lingkungan, rata-rata subjek memiliki sanitasi lingkungan tidak baik yaitu sebanyak 46 subjek $(79,3 \%)$. 
Berdasarkan kuesioner diketahui bahwa sebanyak 72,4 persen subjek memiliki sumber air yang bukan milik sendiri, berbau, berwarna dan berasa, 81,03 persen subjek sudah memiliki jamban yang layak, 84,5 persen subjek sudah mempunyai selokan tertutup dan 46,6 persen subjek sudah mempunyai tempat pembuangan sampah yang kedap air dan tertutup, sehingga masalah utama sanitasi lingkungan yang dialami subjek penelitian adalah pada penggunaan air bersih.

\section{Faktor yang Berisiko terhadap Kejadian Dermatitis}

Hasil analisis hubungan antara faktor-faktor yang berisiko terhadap kejadian dermatitis dapat dilihat pada Tabel 2 berikut:

Tabel 2. Faktor yang Berisiko terhadap Kejadian Dermatitis

\begin{tabular}{|c|c|c|c|c|c|c|c|c|}
\hline \multirow{2}{*}{ Variabel } & \multicolumn{2}{|c|}{ Kasus } & \multicolumn{2}{|c|}{ Kontrol } & \multirow{2}{*}{$p$} & \multirow{2}{*}{ OR } & \multicolumn{2}{|c|}{$95 \% \mathrm{Cl}$} \\
\hline & $\mathrm{n}$ & $\%$ & $\mathrm{n}$ & $\%$ & & & Min & Maks \\
\hline \multicolumn{9}{|c|}{ Riwayat asupan vitamin A } \\
\hline Kurang & 15 & 51,7 & 2 & 6,9 & \multirow[b]{2}{*}{$0,001^{a}$} & \multirow{2}{*}{14,5} & \multirow[b]{2}{*}{2,89} & \multirow[b]{2}{*}{72,39} \\
\hline Cukup & 14 & 48,3 & 27 & 93,1 & & & & \\
\hline \multicolumn{9}{|l|}{ Riwayat asupan seng } \\
\hline Kurang & 18 & 62,1 & 5 & 17,2 & \multirow[b]{2}{*}{$0,001^{b}$} & \multirow[b]{2}{*}{7,9} & \multirow[b]{2}{*}{2,32} & \multirow[b]{2}{*}{26,63} \\
\hline Cukup & 11 & 37,9 & 24 & 82,8 & & & & \\
\hline \multicolumn{9}{|l|}{ Personal hygiene } \\
\hline Tidak baik & 19 & 65,5 & 8 & 27,6 & \multirow{2}{*}{$0,008^{b}$} & \multirow{2}{*}{4,9} & \multirow{2}{*}{1,63} & \multirow{2}{*}{15,25} \\
\hline Baik & 10 & 34,5 & 21 & 72,4 & & & & \\
\hline \multicolumn{9}{|l|}{ Sanitasi lingkungan } \\
\hline Tidak baik & 27 & 93,1 & 19 & 65,5 & \multirow{2}{*}{$0,021^{a}$} & \multirow{2}{*}{7,1} & \multirow{2}{*}{1,395} & \multirow{2}{*}{36,18} \\
\hline Baik & 2 & 6,9 & 10 & 24,5 & & & & \\
\hline
\end{tabular}

aUji Chi-Square Fisher's Exact Test

bUji Chi-Square Continuity Correction

Berdasarkan Tabel 2, diketahui bahwa asupan vitamin A, riwayat asupan seng, personal hygiene, dan sanitasi lingkungan signifikan dengan kejadian dermatitis. Analisis multivariat selanjutnya dilakukan untuk menganalisis variabel yang paling berisiko terhadap kejadian dermatitis.

\section{Faktor yang Paling Berisiko terhadap} Kejadian Dermatitis

Hasil analisis uji regresi logistik ganda menunjukkan faktor yang paling berisiko terhadap kejadian dermatitis adalah riwayat asupan vitamin A dan riwayat asupan seng, selengkapnya dapat dilihat pada Tabel 3 berikut: 
Tabel 3. Faktor Risiko Kejadian Dermatitis

\begin{tabular}{lcccccc}
\hline \multicolumn{1}{c}{ Variabel } & B & \multirow{2}{*}{$p$} & OR & \multicolumn{2}{c}{$95 \% \mathrm{Cl}$} \\
\cline { 5 - 7 } & & & 0,019 & 7,9 & 1,410 & 44,177 \\
\hline Riwayat asupan vitamin A & 2,066 & 1,435 & 0,043 & 4,3 & 1,045 & 16,881 \\
Riwayat asupan seng & 1,307 & 0,051 & 3,7 & 0,994 & 13,742 \\
Personal hygiene & $-3,138$ & & & & \\
Konstanta & & & & & & Maks \\
\hline
\end{tabular}

¿Uji Regresi Logistik Ganda

Subjek yang mempunyai riwayat asupan vitamin A kurang dari kebutuhan berisiko 7,9 kali lebih besar untuk mengalami dermatitis dibandingkan subjek yang mempunyai riwayat asupan vitamin A cukup (95\% Cl: 1,410-44,177). Selain itu, subjek yang mempunyai riwayat asupan seng kurang dari kebutuhan berisiko 4,3 kali lebih besar untuk mengalami dermatitis dibandingkan subjek yang mempunyai riwayat asupan seng yang cukup $(95 \% \mathrm{Cl}: 1,045-16,881)$. Berdasarkan perhitungan probabilitas, subjek yang mempunyai riwayat asupan vitamin $A$ dan riwayat asupan seng yang kurang dari kebutuhan mempunyai risiko 58 persen mengalami dermatitis.

\section{PEMBAHASAN}

\section{Karakteristik Subjek}

Berdasarkan data asupan vitamin A pada penelitian ini, diketahui bahwa balita yang memiliki riwayat asupan vitamin A kurang yaitu sebesar 29,3 persen, angka ini lebih besar dari penelitian sebelumnya yang dilakukan di Boyolali dengan subjek balita usia 1-5 tahun yang menyatakan sebanyak 15,1 persen balita mempunyai asupan vitamin $\mathrm{A}$ yang kurang. ${ }^{22} \mathrm{Hal}$ ini perlu mendapatkan perhatian khusus, karena apabila seorang balita mengalami defisiensi vitamin A maka akan terjadi gangguan masalah klinis pada kulit yang berkaitan dengan imun, efek ini kemudian dikenal dapat meningkatkan mortalitas dari penyakit infeksi. Hal ini disebabkan vitamin A memiliki peranan penting terutama bagi imunitas tubuh. ${ }^{23}$

Berdasarkan analisis SQ-FFQ diketahui bahwa balita yang memiliki asupan vitamin $A$ kurang adalah balita yang jarang mengonsumsi beraneka ragam buah dan sayur. Buah yang biasanya dikonsumsi adalah buah yang diperoleh dari lingkungan dekat rumah tinggal mereka yaitu buah salak, pisang, pepaya, dan belimbing. Selain itu, konsumsi sayur hijau juga tidak banyak, kebanyakan balita hanya mengonsumsi kuah dari sayur yang disajikan oleh orang tua atau pengasuh. Banyak balita yang lebih sering mengonsumsi jajanan seperti wafer, coklat, dan roti kemasan yang mempunyai kandungan vitamin A rendah. Hanya sedikit balita yang mengonsumsi minyak fortifikasi vitamin A karena kebanyakan dari orang tua balita menggunakan minyak goreng curah untuk mengolah makanan.

Data asupan seng yang dikumpulkan pada penelitian ini menunjukkan bahwa masih terdapat 39,7 persen balita yang mempunyai riwayat asupan seng yang kurang, angka ini lebih besar dari hasil penelitian sebelumnya yang dilakukan pada tahun 2017 di daerah yang sama dengan subjek balita usia 2-5 tahun yaitu sebanyak 26,2 persen balita mengalami defisiensi seng. ${ }^{19} \mathrm{Hal}$ ini juga perlu mendapatkan perhatian khusus karena jika seseorang mengalami defisiensi seng maka akan menimbulkan masalah kulit akibat gangguan sel imun berupa reduksi pada 
pengembangan sel $\mathrm{T}$, thymic hormone release dan fungsi sel T. Rendahnya kadar seng dalam tubuh mengakibatkan meningkatnya kejadian infeksi karena terjadi penurunan sistem tanggap kebal. ${ }^{4,5,14}$

Berdasarkan analisis SQ-FFQ diketahui bahwa kandungan seng tinggi pada makanan yang dikonsumsi balita berasal dari susu kental manis dan produk susu formula. Namun, masih terdapat balita yang memiliki asupan seng kurang karena tidak mengonsumsi susu kental manis dan produk susu formula. Selain itu banyak balita yang jarang mengonsumsi makanan hewani seperti hati dan makanan laut, dimana makanan tinggi sumber seng ada pada makanan laut, tiram, daging, dan produk susu banyak terdapat kandungan seng. ${ }^{24}$

Dermatitis juga bisa terjadi karena personal hygiene. Data penelitian menunjukkan bahwa sebanyak $27(46,6 \%)$ subjek penelitian mempunyai personal hygiene yang kurang baik. Berdasarkan data yang diambil, personal hygiene tidak baik pada balita subjek penelitian adalah kebiasaan balita yang menggunakan sabun bergantian dengan anggota keluarga lain, tidak membersihkan/menyikat kuku menggunakan sabun saat mandi, tidak mengganti pakaian setelah berkeringat, menjemur handuk basah di dalam kamar, dan menjemur kasur dan bantal lebih dari dua minggu sekali. Dari kelima kebiasaan buruk yang dilakukan oleh subjek penelitian, kebiasaan yang paling banyak dilakukan adalah menggunakan sabun bergantian dengan anggota keluarga lain. Menurut Irianto sabun digunakan untuk mencuci tubuh saat mandi, oleh buih sabun semua kotoran dan kuman yang melekat mengotori kulit akan lepas dari permukaan kulit. ${ }^{25}$

Pemeliharaan kesehatan kulit tidak dapat terlepas dari kebersihan lingkungan. Data penelitian menunjukkan mayoritas sebanyak 46 $(79,3 \%)$ subjek penelitian mempunyai sanitasi lingkungan yang kurang baik. Penentuan status sanitasi lingkungan subjek penelitian meliputi penggunaan air bersih, ketersediaan jamban keluarga, tempat pembuangan air limbah, dan pembuangan sampah. Berdasarkan hal tersebut, diketahui sebanyak 42 (72,4\%) subjek penelitian mempunyai sarana air bersih yang bukan milik sendiri, berbau, berwarna, dan berasa. Air merupakan suatu sarana untuk meningkatkan derajat kesehatan masyarakat karena air merupakan salah satu media berbagai macam penularan penyakit. ${ }^{26}$ Air yang berkualitas harus memenuhi syarat fisik yaitu tidak berwarna, tidak berasa, dan tidak berbau. Air yang berwarna berarti mengandung bahan koloid dan bahan yang terlarut dalam air yang berbahaya bagi kesehatan. Air yang berbau dan berasa terjadi akibat adanya bahan-bahan organik yang sedang mengalami dekomposisi (penguraian) oleh mikroorganisme air. ${ }^{27}$

\section{Faktor yang Berisiko terhadap Kejadian Dermatitis}

Hasil analisis hubungan menunjukkan ada hubungan riwayat asupan vitamin A dengan kejadian dermatitis. Subjek dengan riwayat asupan vitamin A kurang dari kebutuhan berisiko mengalami kejadian dermatitis 14,5 kali lebih besar daripada subjek dengan riwayat asupan vitamin A cukup. Hasil ini sejalan dengan penelitian di Korea yang menunjukkan bahwa subjek yang mempunyai asupan vitamin $A$ kurang dari kebutuhan berisiko mengalami dermatitis. ${ }^{28}$ Asupan vitamin A membawa efek dalam sistem imun seseorang yaitu dalam imunitas seluler dan humoral, karena selain dibutuhkan untuk mempertahankan keutuhan fungsi dan struktur epitel, vitamin A dibutuhkan dalam respon mitogenik dari limfosit $T$ dan limfosit B serta menjaga keseimbangan $\mathrm{TH} 1$ dan TH2. ${ }^{11,12}$ Vitamin A juga berperan dalam proses diferensiasi sel epidermis. ${ }^{13}$ 
Riwayat asupan seng juga berhubungan dengan kejadian dermatitis. Subjek dengan riwayat asupan seng kurang berisiko mengalami kejadian dermatitis 7,9 kali lebih besar daripada subjek dengan riwayat asupan seng cukup. Hasil penelitian ini sejalan dengan penelitian di Bogor yang menyatakan bahwa kekurangan seng dapat menyebabkan dermatitis. ${ }^{29}$ Seng dibutuhkan oleh tubuh karena merupakan mineral yang membantu keseimbangan metabolisme yang berkaitan dengan respon imun. ${ }^{15}$ Seng memiliki fungsi imunitas antara lain dalam fungsi sel $\mathrm{T}$ dan pembentukan antibodi oleh sel B, serta pertahanan non spesifik. ${ }^{30}$

Variabel perancu pada penelitian ini adalah personal hygiene dan sanitasi lingkungan. Setelah dianalisis, ada hubungan personal hygiene dengan kejadian dermatitis dimana besar risiko subjek dengan personal hygiene tidak baik adalah 4,9 kali lebih besar daripada subjek dengan personal hygiene tergolong baik. Hasil penelitian ini sejalan dengan penelitian yang dilakukan pada balita di wilayah kerja UPTD Puskesmas Sukaraya yang menyatakan bahwa ada hubungan personal hygiene dengan keluhan penyakit kulit. ${ }^{31}$

Personal hygiene kurang dan menurunnya daya tahan tubuh menyebabkan bakteri, virus, jamur, dan parasit mudah masuk ke dalam tubuh. ${ }^{21}$ Kebersihan kulit diperoleh seseorang dengan mandi yang dilakukan dua kali sehari untuk kebutuhan integritas kulit, sehingga tubuh terhindar dari penyakit infeksi. ${ }^{32}$ Kebersihan kuku bertujuan untuk membersihkan dan mengembalikan batas-batas kulit di tepi kuku ke keadaan normal serta mencegah terjadinya perkembangan kuman penyakit. ${ }^{33}$ Pakaian banyak menyerap keringat dan kotoran yang dikeluarkan oleh kulit. Pakaian bersentuhan langsung dengan kulit sehingga apabila pakaian yang basah karena keringat dan kotor akan menjadi tempat berkembangnya bakteri di kulit. ${ }^{25}$ Menurut sebuah penelitian, pemakaian handuk tidak diperbolehkan dipakai bersamasama karena mudah menularkan bakteri dari penderita ke orang lain. Apalagi bila handuk yang dipakai tidak dijemur di bawah terik matahari atau tidak dicuci dalam jangka waktu yang lama maka kemungkinan jumlah bakteri yang ada pada handuk akan meningkat dan sangat berisiko menimbulkan penyakit kulit. Kuman penyebab penyakit kulit paling sering hidup dan berkembang biak di perlengkapan tidur. Oleh sebab itu perlu menjemur kasur dan mengganti seprei seminggu sekali, sehingga dapat mengurangi perkembangbiakan kuman penyakit kulit. ${ }^{34}$

Variabel perancu lain terkait dengan kejadian dermatitis adalah sanitasi lingkungan. Hasil analisis menunjukkan ada hubungan sanitasi lingkungan dengan kejadian dermatitis dimana subjek yang mempunyai sanitasi lingkungan yang tidak baik berisiko mengalami kejadian dermatitis 7,1 kali lebih besar daripada subjek yang mempunyai sanitasi lingkungan yang baik. Hasil penelitian ini sejalan pula dengan penelitian yang dilakukan oleh Agsa yang menyatakan bahwa ada hubungan antara saniatsi lingkungan dengan keluhan penyakit kulit. ${ }^{21}$

Sanitasi lingkungan merupakan salah satu status kesehatan suatu lingkungan yang mencakup kebersihan air, jamban, pembuangan limbah air, dan pembuangan sampah. ${ }^{35}$ Limbah air dapat menjadi tempat berkembang biaknya mikroorganisme patogen dan menjadi media transmisi penyakit menular apabila pembuangannya tidak memenuhi persyaratan teknis. ${ }^{36}$ Feses dapat menjadi media berbagai penyakit apabila tempat pembuangan feses (jamban) tidak memenuhi kriteria jamban sehat. Secara umum pembuangan sampah yang tidak memenuhi syarat kesehatan lingkungan akan dapat mengakibatkan berkembang biaknya serangga dan tikus, dapat menjadi sumber 
pengotoran tanah, pencemaran air dalam tanah, dan pencemaran udara, serta dapat menjadi tempat berkembang biaknya kuman penyakit yang membahayakan kesehatan. ${ }^{21}$

\section{Faktor yang Paling Berisiko terhadap Kejadian Dermatitis}

Berdasarkan uji regresi logistik ganda, riwayat asupan vitamin $\mathrm{A}(p=0,019)$ dan riwayat asupan seng $(p=0,043)$ merupakan faktor yang paling berisiko mengalami kejadian dermatitis. Hasil penelitian ini sejalan dengan penelitian sebelumnya yang menunjukkan bahwa asupan vitamin A dan seng yang kurang dari kebutuhan berisiko mengalami dermatitis. ${ }^{28,29}$ Personal hygiene tidak termasuk faktor yang paling memengaruhi dermatitis dikarenakan tidak semua yang mengalami dermatitis mempunyai personal hygiene yang kurang baik begitupun dengan yang tidak mengalami dermatitis tidak semua mempunyai personal hygiene yang baik. Sanitasi lingkungan juga tidak termasuk faktor yang paling berisiko memengaruhi dermatitis dikarenakan hampir seluruh subjek penelitian memiliki sanitasi lingkungan yang tidak baik.

Berbagai pajanan mikroorganisme di lingkungan tempat tinggal individu ikut membentuk pola perkembangan respons imun individu yang memengaruhi kerentanan seseorang terhadap kejadian penyakit infeksi. ${ }^{37}$ Respons imun non-spesifik dan spesifik pada kenyataannya tidak terjadi secara terpisah, tetapi terjadi dengan saling melengkapi dan memengaruhi satu sama lain. Imunitas nonspesifik berperan sebagai pertahanan pertama terhadap agen infeksius, dimana mikroorganisme patogen akan dihancurkan sebelum berkembang biak dan sebelum menimbulkan infeksi. Apabila pertahanan pertama tidak dapat mencegah infeksi sehingga menimbulkan penyakit, maka sistem imun spesifik akan diaktivasi.
Penyembuhan melalui respon imun spesifik akan meninggalkan memori imunologi yang spesifik sehingga infeksi selanjutnya dengan agen infeksius yang sama tidak akan menimbulkan penyakit. ${ }^{38}$

Asupan vitamin, mineral, dan elemen penting untuk sistem kekebalan tubuh. Kurangnya asupan vitamin dan mineral dapat menjadi salah satu penyebab terjadinya dermatitis. Seng adalah salah satu elemen penting yang berfungsi sebagai kofaktor untuk beberapa enzim yang terlibat dalam metabolisme dan pertumbuhan sel. Seng sangat penting untuk semua sel yang berkembang biak serta sistem kekebalan tubuh. ${ }^{39}$ Sekitar 30 persen seng ( $\left.\mathrm{Zn}\right)$ dalam makanan diserap di usus halus. Dari seluruh seng yang diserap, sebesar 80 persen terikat oleh albumin darah dan 20 persen terikat pada a2-makroglobulin. Seng dalam tubuh disimpan dalam jaringan perifer termasuk kerangka $(60 \%)$, tulang (30\%), hati (5\%), dan kulit (5\%). ${ }^{40}$ Dengan demikian, kulit adalah jaringan ketiga di antara jaringan dengan seng paling banyak di dalam tubuh. Di kulit manusia, seng lebih banyak berada di epidermis daripada di dermis. Konsentrasi seng di epidermis adalah $60 \mathrm{mg} / \mathrm{g}$ dan di dermis $40 \mathrm{mg} / \mathrm{g} .{ }^{41}$

Seng berperan sebagai kofaktor untuk hormon timulin. Defisiensi hormon ini menyebabkan kegagalan dalam proliferasi dan menurunnya fungsi sel limfosit $\mathrm{T}^{42}$ Seng mampu memodulasi reseptor yang diperlukan untuk mengenali produk sitokin yang dilepaskan oleh makrofag atau sel $\mathrm{T}$ jika terjadi reaksi radang karena terpapar faktor risiko. Seng juga mampu menyebabkan sel limfosit berdiferensiasi dan berproliferasi karena adanya peningkatan produksi limfokin akibat peningkatan enzim katalase dan enzim superoksida dismutase (SOD). Jika terjadi kegagalan dalam diferensiasi dan proliferasi maka akan terjadi penurunan 
fungsi sel limfosit $\mathrm{T}$, dimana limfosit $\mathrm{T}$ pada sistem kekebalan seluler berfungsi untuk mengeliminasi antigen dalam intrasel untuk mencegah terjadinya infeksi. ${ }^{29}$

Riwayat asupan vitamin A yang kurang memengaruhi imunitas seluler yaitu memengaruhi kekebalan alami antara lain dapat menurunkan berat kelenjar timus. Penurunan berat kelenjar timus akan menurunkan aktivitas timulin sehingga menurunkan jumlah limfosit yang memengaruhi diferensiasi dan fungsi sel T. ${ }^{11,43}$ Vitamin A terutama retinol juga memengaruhi diferensiasi limfosit B. ${ }^{44}$ Selain itu, defisiensi vitamin $A$ menyebabkan integritas mukosa epitel terganggu dengan menghalangi fungsi sel-sel kelenjar yang mengeluarkan mukus dan digantikan oleh sel-sel epitel bersisik dan kering (keratinized). Kulit menjadi kasar dan luka sukar sembuh. Membran mukosa tidak dapat mengeluarkan cairan mukus dengan sempurna sehingga mudah terserang bakteri (infeksi). ${ }^{30}$

Selain itu perubahan asupan vitamin A memberikan efek pada absorpsi, status dan fungsi seng. Defisiensi vitamin A yang berat mengakibatkan berkurangnya absorpsi dan transpor seng dari limpa dan hati. ${ }^{45}$ Bila tubuh kekurangan asupan vitamin A maka vitamin A dimobilisasi dari hati dalam bentuk retinol yang diangkut oleh Retinol Binding Protein (RBP), yang disintesis di dalam hati. RBP mengikat 1 molekul retinol. Dalam darah seng ditransportasikan sebagian melalui o-globulin sebanyak 20 persen dan retinol juga terikat pada protein transpor yang sama. Tetapi jika retinol dari makanan (atau prekursornya) berkurang maka kadar serum RBP akan turun. ${ }^{46}$

\section{KESIMPULAN}

Riwayat asupan vitamin A dan seng yang rendah akan meningkatkan risiko anak mengalami dermatitis. Dalam penelitian ini, riwayat asupan vitamin A yang rendah berisiko 7,9 kali lebih besar mengalami dermatitis, sedangkan riwayat asupan seng yang rendah berisiko 4,3 kali lebih besar mengalami dermatitis.

\section{SARAN}

Pencegahan dermatitis pada balita dapat dilakukan dengan pemenuhan asupan vitamin A sesuai kebutuhan yang berasal dari konsumsi buah dan sayur berwarna kuning, oranye, dan merah seperti wortel, tomat, pepaya, semangka, labu, jeruk, dan beberapa produk makanan seperti mentega/margarin dan susu. Pemenuhan asupan seng berasal dari makanan hewani seperti hati, daging, tiram, ikan laut, dan makanan laut lainnya. Selain itu, orang tua juga harus memperhatikan kebersihan diri anak dan keluarga serta sanitasi lingkungan tempat tinggal.

\section{UCAPAN TERIMA KASIH}

Terima kasih kepada dosen pembimbing, seluruh responden dan subjek penelitian serta pihak-pihak yang telah membantu berjalannya penelitian ini.

\section{DAFTAR PUSTAKA}

1. Suhardimansyah, Suaib RS, Dahlan NH. Analisis Faktor Risiko Penyakit Dermatitis di Wilayah Kerja Puskesmas. Skripsi. Kendari: Universitas Halu Oleo, 2012.

2. World Health Organization. Epidemiology and Management of Common Skin Diseases in Children in Developing Countries. Geneva: World Health Organization; 2005.

3. Lawita AJ, Sarimin S, Karundeng MY. Hubungan Faktor Lingkungan dengan Kejadian Dermatitis pada Anak Usia Sekolah di Desa Tabang Barat Kecamatan Rainis Kabupaten Kepulauan Talaud. Jurnal E-Ners. 2015;3(2). 
4. Selmi $C$, Invernizzi $P$, Zuin $M$, Ansari $A A$, Gershwin ME. Evaluation of Immune Function in Nutritionally At-Risk Patient. In: Gershwin ME, Nestel P, Keen CL, editors. Handbook of Nutrition and Immunity. New Jersey: Humana Press; 2004. p. 2.

5. Wonggokusuma G. Akrodermatitis Enteropatika dan Defisiensi Seng. Cermin Dunia Kedokteran. 2015;42(12):914-7.

6. Ramos JM, Moles-Poveda P, Tessema D, Kedir M, Safayo G, Tesfasmariam A, et al. Skin Problems in Children Under Five Years Old at A Rural Hospital in Southern Ethiopia. Asian Pac J Trop Biomed. 2016;6(7):625-9.

7. Nutten S. Atopic Dermatitis: Global Epidemiology and Risk Factors. Ann Nutr Metab. 2015;66 suppl1:8-16.

8. Ludfi AS, Agustina L, Fetarayani, Baskoro, Gatot. Asosiasi Penyakit Alergi Atopi Anak dengan Atopi Orang Tua dan Faktor Lingkungan. Jurnal Peny Dalam. 2012;13(1);53-62.

9. Winaktu GJ. Peran Zinc pada Respons Imun. J Kedokt Meditek. 2011;17(44):24-34.

10. Ramakrishnan $U$, Webb AL, Ologoudou Ka. Infection, Immunity, and Vitamins. In: Gershwin ME, Nestel P, Keen CL, editors. Handbook of Nutrition and Immunity. New Jersey: Humana Press; 2004. p. 93.

11. Subowo. Imunologi Klinik. Edisi Ke-2. Bandung: Sagung Seto; 2013.

12. Azrimaidaliza. Vitamin A, Imunitas dan Kaitannya dengan Penyakit Infeksi. Jurnal Kesehatan Masyarakat. 2007;1(2):90-6.

13. Shils ME, Shike M. Modern Nutrition in Health and Disease. 10th ed. Philadelphia: Lippincott Williams \& Wilkins. 2006;34(9):2514.

14. SatriyoA, Rihatmadja R. Peran Seng di Bidang Dermatologi. MDVI. 2014;41(1):42-51.
15. Hendarto A, Pringgadini K. Nilai Nutrisi Air Susu Ibu. Buku Bedah ASI. diunduh dari www.idai.or.id/artikel/klinik/asi/nilai-nutrisiair-susu-ibu, tanggal 30 Maret 2017

16. Kambe T, Fukue K, Ishlda R, Shiho M. Overview of Inherited Zinc Deficiency in Infants and Children. Journal Nutrition Science Vitaminol. 2015;61:44-6.

17. Maulida A, Pramono A. Gambaran Asupan Vitamin A, Kadar Serum Seng, dan Status Gizi pada Anak Usia 9-12 Tahun. Journal of Nutrition College. 2015;4(2):323-8.

18. Rahman MM, Vermund $\mathrm{SH}$, Wahed MA, Fuchs GJ, Baqui AH, Alvarez JO. Simultaneous Zinc and Vitamin A Supplementation in Bangladeshi Children: Randomised Double Blind Controlled Trial. BMJ. 2001;323(7308):314-8.

19. Candra A. Pengaruh Suplementasi Seng terhadap Berat Badan dan Tinggi Badan Balita. Journal of Nutrition Health. 2017;5(1). P.37-44.

20. 'Arasi F. Survei Konsumsi Makanan. In: Hardinsyah, Supariasa IDN, editors. IImu Gizi Teori dan Aplikasi. Edisi I. Jakarta: Penerbit Buku Kedokteran EGC; 2014. p. 140-9.

21. Sajida A, Santi DN, Naria E. Hubungan Personal Hygiene dan Sanitasi Lingkungan dengan Keluhan Penyakit Kulit di Kelurahan Denai Kecamatan Medan Denai Kota Medan Tahun 2012. Jurnal Lingkungan dan Kesehatan Kerja. 2013;2(2):38-45.

22. Tiyas Fajria Agustyani. Tingkat Pengetahuan Ibu tentang Vitamin A pada Balita di Polindes Singosari Mojosongo Boyolali. Skripsi. Surakarta: STIKES Kusuma Husada, 2012.

23. Muhilal. Highlight of Fourty Years Research on Vitamin A Deficiency at the Center for Research and Development in Food an Nutrition. In: Scientific Speech on 
Retirement. Bogor: Center for Research and Development in Food and Nutrition;2005.

24. Andriani M, Wirjatmadi B. Gizi dan Kesehatan Balita Peranan Mikro Zinc pada Pertumbuhan Balita. Edisi I. Jakarta: Kencana; 2014.

25. Irianto K. Mikrobiologi:Menguak Dunia Mikroorganisme. Bandung: CV Yrama Widya; 2007.

26. Suares M, Making V, Jap J. Air Kesehatan dan Kehidupan. Institute of Health Science Citra Husada Mandiri Kupang. 2017. Diunduh dari: http://chmk.ac.id/wp/airkesehatan-dan-kehidupan/, tanggal 20 Maret 2018

27. Denis R. Kualitas dan Kuantitas Air Bersih untuk Pemenuhan Kebutuhan Manusia. 2010. Diunduh dari: https://dokumen. tips/documents/kualitas-dan-kuantitasair-bersih-untuk-pemenuhan-kebutuhan560c44eb752e9.html, tanggal 20 Maret 2018.

28. Oh SY, Chung J, Kim MK, Kwon SO, Cho $\mathrm{BH}$. Antioxidant Nutrient Intakes and Corresponding Biomarkers Associated with The Risk of Atopic Dermatitis in Young Children. European Journal of Clinical Nutrition. 2010;64:245-52.

29. Widhyari SD. Peran dan Dampak Defisiensi Zinc ( $\mathrm{Zn}$ ) terhadap Sistem Tanggap Kebal. Wartazoa. 2012;22(3):141-8.

30. Andriani M, Wirjatmadi B. Gizi dan Kesehatan Balita Peranan Mikro Zinc pada Pertumbuhan Balita. Edisi I. Jakarta: Kencana Prenada Media Grup; 2014.

31. Afriani B. Hubungan Tingkat Pengetahuan dan Personal Hygiene dengan Kejadian Dermatitis pada Anak Balita di Wilayah Kerja UPTD Puskesmas Sukaraya Tahun 2016. Cendekia Medika. 2016;2(1):1-6.
32. Wolf LV. Dasar-Dasar IImu Keperawatan. Jakarta: Gunung Agung; 2000. p. 51.

33. Stevens PJM, Bordui F, Van der Weyde JAG. IImu Keperawatan. Jakarta: EGC; 1999.

34. Andayani LS. Perilaku Santri Dalam Upaya Pencegahan Penyakit Skabies di Pondok Pesantren Ulumu Qur'an Stabat. USU e-Journal. 2005;9(2):172-77.

35. Sukut SS, Arif YS, Qur'aniati N. Faktor Kejadian Diare pada Balita dengan Pendekatan Teori Nola J. Pender di IGD RSUD Ruteng. Jurnal Pediomaternal. 2015;3(2):230-49.

36. Kusnoputranto $\mathrm{H}$. Kesehatan Lingkungan. Jakarta: Gramedia Pustaka Utama; 2000.

37. Humas FK UI. Kebersihan Lingkungan Pengaruhi Respon Imun Individu. 2015. Diunduh dari: http://fk.ui.ac.id/berita/ kebersihan-lingkungan-pengaruhi-responimun-individu.html, tanggal 5 Juli 2018.

38. Darwin E. Imunologi dan Infeksi. Padang: Andalas University Press; 2006.

39. Maywald M, Rink L. Zinc Homeostasis and Immunosenescence. J Trace Elem Med Biol. 2015;29:24-30

40. Ogawa Y, Kawamura T, Shimada S. Zinc and Skin Biology. Archives of Biochemistry and Biophysics. 2016; 611:113-9.

41. Inoue $Y$, Hasegawa S, Ban S, Yamada T, Date $\mathrm{Y}$, Mizutani $\mathrm{H}$, et al. ZIP2 Protein, a Zinc Transporter, is Associated with Keratinocyte Differentiation. J Bio. Chem. 2014: 289 (31):21451-62.

42. Prasad AS, Beck FW, Bao B, Fitzgerald JT, Snell DC, Steinberg JD, et al. Zinc Supplementation Decreases Incidence of Infections in The Elderly: Effect of Zinc on Generation of Cytokines and Oxidative Stress. Am J Clin Nutr. 2007;85(3):837-44. 
43. Villamor E, Fawzi WW. Effects of Vitamin A Supplementation on Immune Respon and Correlation with Clinical Outcomes. Clin Microbiol Rev. 2005;18(3):446-64.

44. Pratiwi YS. Kekurangan Vitamin $A(K V A)$ dan Infeksi. The Indonesian Journal of Health Science. 2013;3(2):207-10.

45. Rahman MM, Wahed MA, Fuchs GJ, Baqui AH, Alvares JO. Synergiztic Effect of Zinc and Vitamin A on The Biochemical Indexes of Vitamin A Nutrition in Children. The American Journal of Clinical Nutrition. 2002;75(1):92-98.

46. Berdanier CD, Berdanier LA, Zempleni J. Advanced Nutrition: Macronutriens, Micronutrients and Metabolism. Florida: CRC Press; 2009. P. 309-482. 